\title{
Cutting the apron strings: the South African experience of decolonisation
}

\author{
GE DEVENISH ${ }^{1}$
}

\begin{abstract}
Decolonisation is a recurring constitutional and political theme in the process of change and reform in South Africa's history during the $20^{\text {th }}$ century. The constitutional emancipation of the erstwhile Union of South Africa and the subsequent internal decolonisation of designated black ethnic population and cultural groups, are two kindred processes which have interesting similarities, but also important differences. The former involved British Imperialism, the latter involved Afrikaner Nationalism and African Nationalism. The former was a natural, legitimate and spontaneous process, the latter was an artificial process that was induced by Afrikaner Nationalism, that was spurned internationally and domestically by the the international community of nations and indigenous people of South Africa respectively.

The article examines the legitimacy of the process of the decolonisation of the Union of South Africa resulting in its independence, followed by the adoption of a republican form of government. In contrast, a comparison is made with the controversial and questionable evolution of the Bantustans, which emerged out of the erstwhile native reserves, a stratagem designed in effect to thwart the liberation struggle for a truly democratic form of government for all the people of South Africa. This pseudo decolonisation was an analogous process to that of genuine decolonisation. The former involved political fragmentation, whatever it was designated, that in effect, denied to the indigenous people, freedom and liberation for decades. As an odyssey it was a very protracted and painful process. Ultimately, in a belated and circuitous manner, after the inordinate suffering and oppression of South Africa's indigenous people, a genuine democracy in a unified and consolidated state for all the people of South Africa was to transpire. This was liberation and not decolonisation, and was the final stage in the historic and traumatic process for South Africa.

It is also argued that only with the inception of the Interim Constitution, following the first historic democratic election of 27 April 1994, did South Africa and its people adopt an authentic democratic and republican constitution.
\end{abstract}

Keywords: Union of South Africa, Status, dominions, decolonisation, liberation movements, Afrikaner nationalism, African nationalism.

\section{Introduction}

Their purpose is to capture the vanguard, to turn the movement of liberalisation towards the right and to disarm the people; quick, quick, lets decolonize. Decolonize the Congo, before its turns into another Algeria. Vote the constitutional framework for all

1. Prof. GE Devenish is a senior research associate in the School of Law, University of KwaZulu-Natal. The article is based on a paper presented at the European Society of Comparative Legal Historians, University of Amsterdam, 11 July 2012. 


\section{Africa, create the Communaute, renovate the same Communaute, but for God's sake let's decolonize quick. ${ }^{2}$}

This article sets out a brief chronological and comparative account of some of the different manifestations of decolonisation. Thereafter, the process of emancipation from colonial tutelage in the erstwhile Union of South Africa, and the subsequent emergence of the Bantustans as part of the policy of so-called "grand" apartheid, are discussed. Decolonisation is a political phenomenon in terms of which a dependent territory is emancipated from colonial tutelage. According to Encyclopedia Britannica, ${ }^{3}$ one of the major international political changes after the Second World War was the emergence of more than 50 new sovereign states. Decolonisation is considered to be one the most seminal political, international and cultural issues of the contemporary world. It has involved the transformation of an obsolete imperial hegemony, and the emergence of new nations in the global order. This epic change was to mobilise the concepts and practice of "national sovereignty, the right to self-determination and a portfolio of human rights". ${ }^{4}$

Before 1945, Western European nations had ruled over vast territories in the Middle East, Asia and Africa. ${ }^{5}$ All of this was to change fundamentally in the decades after the war. The lineage of decolonisation, however, goes back very much further than this period. Great Britain's prized and prosperous 13 North American colonies were to successfully wage a revolutionary war, which culminated in an historic break with the British Crown and Empire, and as a result they were collectively recognised as an independent nation by the Treaty of Paris in $1783 .{ }^{6}$ This resulted in the emergence of the United States of America, which was the first territory colonised by Europeans to achieve constitutional and international independence, and the first independent state in the New World. This was to be followed by Haiti, which declared itself independent from metropolitan France, and which also became the first indigenous nation to be emancipated from European rule. ${ }^{7}$ Subsequently, the Spanish and Portuguese territories in the Americas obtained independence. ${ }^{8}$ Decolonisation was also to occur in other parts of the world, such as in the Ottoman Empire. This involved mainly Christians in the Balkans, who had been ruled by the Turks of the Ottoman Empire, and obtained their independence during the 19th Century. This was the process that "peaked at the time of the Ottoman defeat in the Russo-Turkish War of 1877-78". "The states involved in this decolonisation process were Egypt, Greece, Bulgaria, Romania, Serbia and

\footnotetext{
2 F Fannon The Wretched of the Earth (1990) at 53.

3 1993, Vol. 18 at 720.

4 See: "Darwin speaks on Decolonisation as a History of Failure", available at: http://national history center.org/tag/decolonization/ .( Accessed on 27 July 2013).

Encyclopaedia Britannica (1993), Vol. 18 at 720.

http://en.wikipedia.org/wiki/Delonization, at 2. (Accessed on 29 July 2013)

See: "Decolonisation", Slider Encyclopaedia, available at: http://enc.slider.com/Enc/Decolonization, at 3.

$8 \quad$ Ibid. Brazil obtained independence from Portugal in 1808. This was followed by Paraguay (1813), Argentina (1816), Chile (1818), Columbia(1819), the Dominican Republic (1821), Nicaraqua (1821), Honduras(1821), Guatemala (1821), El Salvador (1821), Costa Rica and Mexico (1821), Ecuador (1822), Peru (1824), Bolivia (1824) and Cuba(1865) - all of whom obtained independence from Spain.(Accessed on 27 July 2013).

Ibid.
} 
Montenegro. In the British Empire, the colonies that had substantial white populations such as Canada, Australia, New Zealand and South Africa - were incrementally granted greater measures of self-government, that in fact constituted a process of decolonisation. This historic process was precipitated by the famous report of Lord Durham, ${ }^{10}$ and was explained in Keith's book dealing with the advent of representative and then responsible government, in such colonies - which then became dominions. ${ }^{11}$ Durham stated that:
[i]t is difficult to understand how any English statesman could have imagined that representative and irresponsible government could be successfully combined ${ }^{12}$... (since) ... the colonial demagogue bids high popularity without fear of exposure. Hopelessly excluded from power he expresses the wildest opinions and appeals to the most mischievous passions of the people without any apprehension of having his sincerity or prudence tested by being placed into a position to carry his views into effect. ${ }^{13}$

In this regard, Canada was a pioneer. In March 1867, the British parliament enacted the British North America Act, which established the Dominion of Canada. ${ }^{14}$ Next to obtain dominion status was Australia, which it obtained by virtue of the Commonwealth of Australia Act - once again a British statute adopted by the Imperial parliament at Westminster, on 9th July $1900 .{ }^{15}$ This was followed by the Dominion of New Zealand ${ }^{16}$ and Newfoundland, ${ }^{17}$ and then the Union of South Africa in 1910. ${ }^{18}$ Although in 1921-2 the Irish Free State "was added to the list ...", ${ }^{19}$ its constitutional status was to prove to be anomalous since, as explained by J M Kelly, ${ }^{20}$ "the quality of its membership and the motive keeping it up (the desire to retain some formal link with the North) were idiosyncratic." This continued until 1949, "when even informal Commonwealth membership was discontinued". ${ }^{21}$

After the First World War, there was a gradual emergence of independent territories from the defeated powers such as those of the German ${ }^{22}$ and Ottoman Empires. Also in the wake

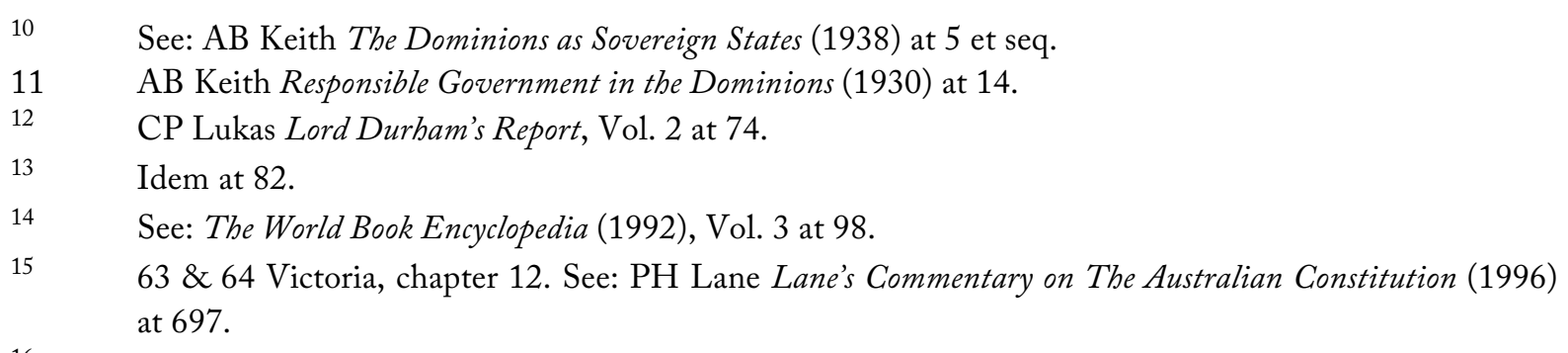

In 1854 the colony of New Zealand became self-governing, with the advent of responsible government - gaining responsibility over all domestic matters other than native policy, which was granted in the mid-1860s. In 1907, at the request of the New Zealand parliament, King Edward VII proclaimed dominium status for the country. In 1947, it adopted the Statute of Westminster, confirming that the British parliament could no longer legislate for it without its consent.

This territory became a province of Canada in 1949. See: The World Book Encyclopedia (1992), Vol. 14 at 178 .

AB Keith The Dominions as Sovereign States (1938) at 151.

Ibid.

JM Kelly The Irish Constitution (1984) at xxvii.

Ibid.

In this regard, German West and East Africa should be mentioned. The former became the mandated territory of South West Africa, which was administered by South Africa, and became independent as the state of Namibia in 1990. The latter became Tanganyika, was placed under United Kingdom trusteeship, became independent in 1961, and in 1962 merged with the island of Zanzibar to become Tanzania. See: Slider Encyclopedia, available at: http://enc.slider.com/Enc/Decolonization, at 7. (Accessed on 27 July 2013). 
of the war, the Austro-Hungarian Empire disintegrated - from which emerged its component parts, namely Austria, Hungary, Bosnia-Hercegovina, Bohemia, Moravia and Galicia. ${ }^{23}$ This was in effect a process of de facto decolonisation, and it flowed from the Fifth of President Woodrow Wilson's Fourteen Points. ${ }^{24}$ From the latter emerged the establishment of the Mandate System ${ }^{25}$ in relation to the colonies of the defeated powers Germany and Turkey - such as German South West Africa, and Palestine - both of which were to spawn decolonisation problems of their own kind. The tempo of decolonisation ${ }^{26}$ changed rapidly after the Second World War, with "43 states achieving independence between 1956 and 1960, 51 between 1961 and 1980 and 23 from 1981". ${ }^{27}$ By resolution, a milestone of cardinal importance designated the Declaration of the Granting of Independence to Colonial Countries and Peoples, was adopted in 1960. ${ }^{28}$ Thereafter, the end of the Cold War - involving the disintegration of the monolithic Soviet Union and its satellite client states - was tantamount to a form of decolonisation. ${ }^{29}$ According to the Huffington Post, ${ }^{30}$ there are still 16 territories around the world that have yet to achieve decolonisation - the most notable being Western Sahara, which has fought for more than 35 years to achieve self-determination in relation to Morocco. ${ }^{31}$

\section{Union of South Africa}

The legitimacy of the process of decolonisation of the Union of South Africa - resulting in its independence and followed by the adoption of a republican form of government - is now examined. In contrast, a comparison is made with the controversial and questionable evolution of the Bantustans, which emerged out of the erstwhile native reserves - a stratagem designed, in effect, to thwart the struggle for a truly democratic form of government for most South Africans. It is submitted that this pseudo-decolonisation was a process analogous to genuine decolonisation. The former involved ethnic fragmentation by means of unilateral partition, whatever it was designated, denied to the indigenous people of South Africa as a whole, freedom and liberation for decades. As an odyssey, it was a very protracted and painful process. What is occurring at present in relation to Palestine - with the so-called two state scenario - is in fact analogous, to some extent, to the decolonisation of the Bantustans in South Africa. However, the emergence of South Sudan, previously known as Southern Sudan, as Africa's newest independent state - involved bilateral, as opposed to a unilateral,

See: J Cole "Decolonization", International Encyclopedia of the Social Sciences, available at: http://www.encyclopedia.com/topic/Deconolisation.aspx, at 5. (Accessed 27 July 2013). http://www.huffingtopost.com/tag/decolonization. (Accessed on 27 July 2013).

31 In 1976, colonial rule from Spain terminated over Western Sahara, but the territory was partitioned between Mauretania and Morocco. The latter subsequently annexed the entire territory in 1979, rendering the declared independence of Saharawi Arab Democratic Republic ineffective - to the present time. See: Slider Encyclopedia, available at: http://enc.slider.com/Enc/Decolonsation. (Accessed 29 July 2013).
} 
partition. ${ }^{32}$ This was also the position with the traumatic emergence of India and Pakistan in 1947, by virtue of partition..$^{33}$ As far as India was concerned, important incremental changes and reforms were made to the Raj, "culminating in the Government of India Act" of 1935. ${ }^{34}$ Complete independence was delayed until after the Second World War, and was then to involve the tragic and bloody process of partition - in an attempt to separate the predominantly Hindu and Muslim parts of erstwhile British India. Belatedly, East Pakistan achieved independence in 1971, as Bangladesh. ${ }^{35}$

Despite the oppression of the African people - inherent in the Bantustan policy, which formed an integral part of the policy of apartheid - ultimately, and in a belated and circuitous manner, a genuine democracy in a unified and consolidated state for all the people of South Africa was to transpire. This was a negotiated process of liberation and not essentially decolonisation, and was the final stage in the historic and prolonged process for South Africa - ensuring democracy and freedom for South Africa and all its diverse people.

Decolonisation is, however, a recurring constitutional and political theme in the process of change and reform in South Africa's history during the 20th century. The constitutional emancipation of the erstwhile Union of South Africa and the subsequent internal decolonisation of designated black ethnic and cultural groups, are two kindred processes which have interesting similarities - but also important differences. Contrasting the two manifestations, the former involved British imperialism, while the latter was precipitated by a conflict between Afrikaner nationalism and African nationalism. The former was a natural, legitimate and spontaneous process, while the latter, it is submitted, was an artificial process that was induced by Afrikaner nationalism - that was spurned internationally, and domestically by the vast majority of South Africa's indigenous people.

\section{Formation of the Union of South Africa}

An important milestone in the drawn-out saga of decolonisation occurred on 31 May 1910, when the Union of South Africa was born into what was designated as the Third British Empire - that marked the emergence of dominion status for certain colonies of the Empire. ${ }^{36}$ The emergence of the Union of South Africa constituted an important symbolic, rather than

South Sudan became an independent state on 9 July 2011. This followed a referendum in which $98.83 \%$ of the vote supported the creation of the new state. It is a member of the United Nations as a member state, a member of the African Union, and a member of the intergovernmental authority on development. In July 2012, South Sudan signed the Geneva Conventions. See: "South Sudan", available at: http://en.wikipedia.org/wiki/Southern-sudan, at 1.(Accessed 29 July 2013). The New Encyclopaedia Britannica (1993), Vol. 18 at 720. Slider Encyclopaedia, available at: http:enc.slider.com/Enc/Decolonization, at 5. (Accessed 29 July 2013).

This was in 1971, after a nine-month civil war, between East and West Pakistan. See: The World Book Encyclopedia (1992), Vol. 2 at 81.

According to AB Keith The Dominions as Sovereign States (1938) at 3, "England was declared to be an empire long before she possessed any external territories of consequence". The first British Empire came to an end with the recognition - in 1782-83 - of the independence of the 13 American colonies. The second British Empire involved essentially India, for whom Queen Victoria was designated as Empress. The third empire involved the dominions - which was pioneered by Canada, flowing from the Durham report. 
a substantive reform. ${ }^{37} \mathrm{~A}$ new, consolidated state having dominion status, replaced four selfgoverning colonies. A Governor-General, who represented the British monarch and government, replaced the colonial governors. Furthermore, and of great significance, the special powers of the colonial governors in relation to native affairs (the term used at the time to refer to African people), were to vest in the Governor-General-Council - who, according to the convention applicable in the dominions, would act on the advice of the Union Cabinet. This eliminated certain vestiges of independent imperial authority exercised by the imperial government at Westminster. ${ }^{38}$ However, in relation to foreign affairs, the Union Government was constrained by the policy of the British government. ${ }^{39}$ The South Africa Act did, however, create an oligarchic constitution, involving a controversial and racist colour bar since only whites could sit in parliament, and only in the Cape Province was there a qualified non-racial franchise. In the other provinces, only whites were eligible to exercise the franchise.

The process of emancipation from colonial tutelage encapsulated constitutional changes and reforms, allowed the Union to emerge as a sovereign independent state, and ultimately to adopt a republican constitution. The highly-cherished independence that the Boers had lost on the field of battle, was attained by a united South Africa through a peaceful process of reform, and not by violent and revolutionary change. In a very controversial way, South Africa, under a National Party government, was to endeavour to emulate the process of internal decolonisation with regard to African people within her borders, and to establish a constellation of states that were nominally independent. This in some respects was analogous to the Commonwealth of Nations, which had previously been designated the British Commonwealth. ${ }^{40}$ This kind of "internal decolonisation" was Afrikaner nationalism's response to the political demands made by African people and the international community, for internal reform in South Africa. This was an unprecedented process and was perceived internationally as a manifestation of the odious policy of apartheid - rather than a process of genuine reform and liberation. Ultimately it was to fail abysmally and tragically. This will be explored more fully later.

\section{Subordinate Status of Dominions and Early Endeavours to Reform Relationships With Great Britain ${ }^{41}$}

The term 'dominion' was officially accepted in a resolution passed by the participants at the Colonial Conference of $1907 . .^{42}$ It was short for "self-governing Dominions beyond the seas."

37 See AB Keith The Constitutional Law of the British Dominions (1933) at 6, who states that “... by 1911 the right of every Dominion to complete self-determination was conceded". See M Wiechers Staatsreg (1981) at 194, and 185 fns 53 and 54. The Union parliament could not adopt laws having an extraterritorial jurisdiction. Empires (1987) at 52. 
However, the precise meaning of this term was not clear. When the British Prime Minister, David Lloyd George, was asked to explain its meaning, he replied that it was "difficult and dangerous to give a definition." ${ }^{43} \mathrm{He}$ further explained that dominion status for Ireland according to the Articles of Agreement of the Irish treaty - meant that "...Whatever measure of freedom Dominion status gives Canada, Australia, New Zealand or South Africa, that will apply to Ireland." ${ }^{44}$ As a matter of fact and law, however, all the dominions before the enactment of the Statute of Westminster of 1931, were colonial appendages of the United Kingdom - meaning they did not have sovereign independence.

The Dominions, in 1910, were not in law independent or completely self-governing, since they were subject to certain restrictions by the United Kingdom's parliament and government. It was clear from a famous British statute, the Colonial Laws Validity Act, ${ }^{45}$ that de jure, the Union parliament was not sovereign, and that legal sovereignty vested ultimately in the Imperial Parliament at Westminster. The latter was imperial in the sense that it could make laws for overseas dependent states of the Empire, and was sovereign in the sense that such laws when made, prevailed over conflicting laws of the state concerned. However, in practice, and by strong convention, the British government did not interfere in the domestic affairs of the dominions. Initially, dominion status permitted them de facto "complete control over domestic matters", and the dominions "were beginning to make cautious advances beyond their own boundaries." ${ }^{6}$ General Smuts, who was a prominent, brilliant and perceptive member of the Imperial War Cabinet, accurately summed up the position at the Imperial War Conference in 1917, by stating that:

Although in practice there is great freedom, yet in actual theory the status of the dominions is of a subject character. Whatever we may say, whatever we may think, we are subject provinces of Great Britain. That is the actual theory of the Constitution, and in many ways, which I need not specify today, that theory still permeates practice to some extent. ${ }^{47}$

42 KC Wheare The Constitutional Structure of the Commonwealth (1961) at 9 and 10. See also: K Hancock Survey of British Commonwealth Affairs (1918-1939) (1964), Vol. 1 at 47. The conference replaced the noun "colony" with the adjective "colonial" and thereafter the conference circle was constituted by the United Kingdom and "self-governing dominions beyond the seas". This was merely a change of nomenclature and it did not effect a change in legal status. In law, the dominions were still subordinate to the Government and Parliament of the United Nations, and were thus colonies."

KC Wheare The Constitutional Structure of the Commonwealth (1961) at 11. See also: 149 House of Commons Debates 5 S., Col 27-28 (1921).

Ibid.

28 and 29 Vict. C 63 (1965). It should, however, be noted that the British government was less inclined to interfere in the domestic issues of the Union than it would have in such issues relating to mere colonies, that were not dominions. In this regard, see: M Wiechers Staatsreg (1981) at 201. British Commonwealth Affairs (1918-1939) (1961), Vol. 1 at 50.

KN Wheare The Constitutional Structure of the Commonwealth (1961) at 47. Smuts was, in effect, spelling out the divergence between the conventional constitutional position and the strict legal TD, 9(2), December 2013, pp. 309-340. 
Foreign affairs was virtually the exclusive concern of the Imperial Parliament and government, and in those matters involving the conduct of foreign policy, "the conclusion of treaties, the maintenance of peace, or the declaration of war could not be shared." 48

\section{Dominion Efforts to obtain Equality of Statehood}

The legally-subordinate status of the dominions was manifestly apparent when, at the outbreak of the First World War, the "British declaration legally committed the whole Empire, although the dominions had taken no part in the diplomacy which preceded the declaration, nor in the decision which irrevocably committed them to war." ${ }^{49}$ The reason for this was patently clear, in that the dominions were still legally and constitutionally colonies and the change of nomenclature that had occurred in 1907 did not change their legal status despite the operation of the convention of non-interference by Britain in their domestic affairs.

During the war, dominion statesmen like the Canadian Prime Minister, Robert Borden, and General Smuts, began to persistently agitate for a revision of the subordinate status of the dominions. This was to give rise to the famous Resolution IX at the Imperial War Conference of 1917 - relating to the existing and future government of the Empire and its component parts. It was hereby agreed that the post-war adaptation of relationships would have to be based on "a full recognition of the autonomous nations of an imperial Commonwealth." ${ }^{50}$ This resolution was an important milestone in the constitutional evolution and process of reform within the Empire and Commonwealth, although the actual legal status of subordination of the dominions was unaltered. The dominions participated meaningfully in the Peace Treaty of Versailles of 1919 and the adoption of the Treaty of the League of Nations - not as completely independent parties, but as members of the British Empire. ${ }^{51}$ Nevertheless, the relationship between Great Britain and the dominions was undergoing a process of incremental reform, which was to accelerate in the years after the First World War. In this regard, GA Coertze made the perceptive statement "dat die Unie reeds volkeregtelik onafhanglik is, maar nie staatsregelik nie." 52

During the years 1919 to 1926 , the dominions began to assert their desire for complete independence - both domestically and internationally. In pursuance of this, the United

position. Conventions have always played an important role in English law, in terms of developing the actual constitution in a positive way.

Minutes of Proceedings, Imperial Conference 1911. See: Parliamentary Papers (Great Britain) section 1 at B2 (b) at 155. See also: RM Dawson The Development of Dominion Status 1900-1936 (1965) at 11.

RM Dawson The Development of Dominion Status 1900-1936 (1965) at 17.

Idem at 25 .

M Wiechers Staatsreg (1981) at 117.

GA Coertze "Die Wetgewende Orgaan van die Unie van Suid-Afrika" THRHR (1941) at 53, and, by the same author "Die posisie van die Koning as Hoof van die Uitvoerende Gesag van die Unie van Suid-Afrika” THRHR (1939) at 250. 
Kingdom allowed Canada to send a diplomatic envoy to the United States. ${ }^{53}$ What this meant in relation to self-government was explained in an address to the House of Commons, ${ }^{54}$ by Mr Bonar Law, in which he declared that:

"[t]here is not a man in this House who would not admit that the connection of the Dominions with the Empire depends on themselves. Australia, Canada or New Zealand could say tomorrow: We will no longer remain part of the British Empire. We would not force them. Dominion Home Rule means the right to decide for themselves. ${ }^{155}$

This meant metaphorically, that what was being anticipated was that the 'apron strings could be cut'. This was indeed to occur with Burma, and then Ireland. ${ }^{56}$ In relation to the latter, Kelly ${ }^{57}$ states that "when even informal Commonwealth membership was discontinued, it has been unarguable that the State bears the same character internationally as the French or Italian Republic". However, Ireland's departure from the Commonwealth did not in any way lead to international isolation, and must be seen in the light of its turbulent history as a rebellious part of the United Kingdom. Furthermore, its domestic policies based on an exemplary constitution, ${ }^{58}$ were in fact democratic in nature. As far as Burma is concerned, however, it became independent on 4 January 1948, and was named the Union of Burma. ${ }^{59}$ Unlike most other erstwhile colonies and overseas territories, it did not become a member of the Commonwealth. Today it is called Myanmar, which is short for the Republic of the Union of Myanmar. ${ }^{60}$ This country has experienced international isolation as a result of its oppressive domestic policies, from which it is only now beginning to emerge - as a result of political reforms. ${ }^{61}$

\section{Balfour Declaration and Statute of Westminster}

At the Imperial Conference of 1926, the famous Balfour Declaration was adopted. It stipulated that:

Great Britain and the Dominions are autonomous communities within the British Empire, equal in status, in no way subordinate to one another in any aspect of their

$53 \quad$ M Wiechers Staatsreg (1981) at 119.

$54 \quad$ Speech by Mr Bonar Law, 30 March 1920.

See: GD Scholtz Hertzog en Smuts en die Britse Ryk (1975) at 76.

56 This occurred in 1949 when the coalition government under John A Costello repealed the External Relations Act, thereby "severing the only remaining link between Britain and Eire”. The Republic of Ireland was formally declared on 18 April 1949, thereby receiving international recognition. See: The World Book Encyclopedia (1992), Vol. 10 at 377.

57 The Irish Constitution (1984) at xxviii.

58 Ibid.

59 http://en.wikipedia.org/org/wiki/Burma\#History. (Accessed on 30 July 2013).

60 Ibid.

61 Ibid.

TD, 9(2), December 2013, pp. 309-340. 
domestic or external affairs, though united by common allegiance to the Crown, and freely associated as members of the British Commonwealth of Nations. ${ }^{62}$

It is important to note that the Balfour declaration stressed the concept of equality. In this regard, it stated that "Equality means equality of status, not equality of stature. Members differ in power and potential. Equality means no subordination." ${ }^{63}$ In the period before the Second World War, the world "equality" was used, and not the word "independence" - which only became accepted terminology after the Second World War, and firstly in relation to India. ${ }^{64}$

At the time, there was a dichotomy between the theoretical legal position and the constitutional practice that gave rise to certain anomalies. The process of decolonisation and reform reached its climax with the adoption - by the Imperial parliament - of the historic Statute of Westminster, which declared:

No Act of the Parliament of the United Kingdom passed after the commencement of this Act shall extend, or deem to extend, to a Dominion as part of the law of that Dominion unless it be expressly declared in that Act that the Dominion has requested, and consented to the enactment thereof. ${ }^{65}$

The adoption by the Union parliament of the cognate Status of Union Act, ${ }^{66}$ and the Royal Executive and Seals Act, ${ }^{67}$ was complementary in this regard. Section 2 of the Status Act declared that:

The Parliament of the Union shall be the sovereign legislative power in and over the Union, and not withstanding anything in any other law contained, no act of the United Kingdom and Northern Ireland passed after the eleventh day of December 1931 shall extend to the Union as part of the law of the Union, unless extended thereto by an Act of the Parliament of the Union.

This meant that the British parliament could - if it so wished - repeal the Statute of Westminster, by virtue of the doctrine of parliamentary sovereignty.

\section{Constitutional significance of Statute of Westminster and Status Act}

The Union of South Africa, both by Act of the Imperial parliament in 1931, and by a statute of its own parliament in 1934, achieved a constitutional state of complete independence. This was a singular triumph for the idea and practice of a liberal policy of incremental

Report of the Inter-Imperial Relations Committee, Imperial Conference, 1926. See: M Wiechers Staatsreg (1981) at 120-123.

KC Wheare The Constitutional Structure of the Commonwealth (1961) at 20.

Ibid.

$22 \mathrm{Geo}$ V, C 4, section 4.

69 of 1934.

70 of 1934. 
constitutional reform. Although Afrikaner nationalists had rebelled in an effort to reestablish the independence of the erstwhile Boer republics, but without success, in 1914 and against the pro-British Botha government - sovereign independence was to emerge from an incremental process of constitutional evolution and liberal reform and adjustment, and not from armed struggle or revolution. In contrast, the United States secured its independence by force of arms against the British government and Crown. Canada and the other dominions, however, obtained their independence by an evolutionary process of constitutional reform and adjustment, which commenced with the implementation of the recommendations of the Durham Report in 1848. ${ }^{68}$ Belatedly, this process started in the Cape Colony in 1853, when the Colony obtained firstly representative government, and subsequently responsible government in 1872. The Statute of Westminster and the Status Act in fact led to the most fundamental reform that ever occurred in the relationship between South Africa and Great Britain.

The Statute of Westminster constituted a watershed in South Africa's constitutional development, since in terms of it, the Imperial parliament relinquished its sovereignty over the Union and its parliament. The Status Act declared the Union parliament to be the "sovereign legislative power in and over the Union," and thereby this involved a break in legal continuity - since the locus of legal sovereignty had shifted decisively and irrevocably from the Imperial parliament at Westminster to the Union parliament in Cape Town. In a technical tense, a revolution had occurred, and there had been "a judicial recognition of a political fact - a revolutionary break with the past, with subordination." ${ }^{69}$ In this important process of emancipation from colonial tutelage, General Smuts, and in particular, General Hertzog, who was the South African Prime Minister from 1924 to 1939 - played a vital and constructive role. However, the indigenous people of South Africa, who were almost completely disenfranchised because of a colour bar (except for people of colour in the Cape Province, where a qualified franchise prevailed), played no role. ${ }^{70}$

The crucial test with regard to the sovereignty of the Union and its parliament came with the outbreak of the Second World War. ${ }^{71}$ Despite the enactment of both the Statute of Westminster and the Status Act, there was a difference of opinion on this seminal issue which depended on the divisibility or not of the Crown. Was South Africa automatically at

See: M Wiechers Staatsreg (1981) at 111-113.

HR Hahlo and E Kahn The Union of South Africa: The Development of its Laws and Constitution (1960) at 150. See also: Cowan Modern Law Review 15 (1952) at 294, who states that: "There is little doubt that in the eyes of South African courts that the Statute of Westminster had resulted in a formal break in the continuity of the South African legal system." See, however, the critical comments of Hancock (fn 5), who stated that: "The separate South African Grundnorm, if it comes to be established, may look to the Balfour Report or merely the Status of Union Act for the root or title of South African law. Or it may set up a fiction that the Statute of Westminster was a complete and irrevocable abdication of power of the Imperial Parliament. In any case, it will do violence to law or history. Probably both. But it may well be politically fortunate. There is much to be said for stealth and subtlety as methods of revolution, if revolution there must be." jurisprudential odyssey" TSAR (2005) at 553.

FR Scot "End of Dominion Status" SALJ (1947) at 149. See also: GD Scholtz Hertzog en Smuts en die Britse Ryk (1975) at 127. 
war if Great Britain and the monarch were at war with Germany? On the one hand, both $\mathrm{Mr}$ $\mathrm{JH} \mathrm{Hofmeyr}^{72}$ and $\mathrm{Mr} \mathrm{H} \mathrm{Nichols}{ }^{73}$ expressed their belief in the indivisibility of the Crown to the effect that when the king is at war, all his subjects are at war as well. On the other hand, a constitutionally more convincing argument was that the Statute of Westminster and the Status Act had rendered the Crown divisible. This was the view of most speakers in the celebrated neutrality debate, and it was the opinion of both Hertzog and Smuts. The argument between the two generals was not a legal one, but a political one - relating to the desirability of neutrality or war with Nazi Germany. In this regard, the sovereign South Africa parliament had to decide. This it did, in favour of war. ${ }^{74}$ In this regard, Smuts, using a powerful metaphor, expressed the position as follows: "Die beroep is op Caesar gedoen, en Caesar het oordeel gevel." 75 The apron strings had indeed been cut.

One of the fundamental issues relating to the historic constitutional crisis associated with the removal of the coloured voters of the Cape Province from the common role in the 1950s was whether the Statute of Westminster had negated the entrenched clauses of the South Africa Act. There was also a dispute as to whether entrenchment imposed a restriction on the Union's sovereignty as an independent state. Centilivres CJ clarified the position, with the explanation that: ${ }^{76}$

The Union is an autonomous state in no way subordinate to any country in the world. To say that the Union is not a sovereign state simply because its parliament functioning bicamerally has not the power to amend certain sections of the South Africa Act, is to state an absurdity.

\section{Republican Status}

Although India wished to become a republic, it desired to retain its membership of the Commonwealth. This was facilitated by a "formula ... which merely described the King as the Head of the Commonwealth and the Crown as the symbol of the free association of its independent member states". ${ }^{77}$ In 1949, when the Commonwealth Prime Ministers' Conference granted India the right to retain its Commonwealth membership, "although it had become a republic, Dr Malan had insisted that all the Commonwealth countries had an equal right with Britain to say whether republican India would remain in the Commonwealth." ${ }^{78}$ This set an important precedent - that republican status was not

72

Hansard House of Assembly Debates, col 74, 4 September 1939.

Ibid.

See: M Wilson and L Thompson (eds) The Oxford History of South Africa (1978) at 382.

JC Smuts Groter Suid-Afrika: Planne Vir n Beter Wereld (1941) at 131. See also: N Mansergh Survey of British Commonwealth Affairs (1939-1952) (1968) at 3.

Harris and Others $v$ Minister of the Interior and Another 1952 SA (2) A 428 and 468.

ME Chamberlain Decolonization The Fall of European Empires (1987) at 53.

M Wilson and L Thompson (eds) The Oxford History of South Africa (1978) at 393. 
incompatible with Commonwealth membership. Pakistan and Ceylon were to follow India's example in 1955 and 1956 respectively. This development was of considerable importance for South Africa - with its strong republican sentiments and traditions. Membership of the Commonwealth entailed many diplomatic, cultural and economic advantages.

On 31 May 1961, 51 years after the advent of the establishment of the Union, the Republic of South Africa came into being. The attainment of the Republic was the consummation of an historic political and constitutional struggle by Afrikaner nationalism in South Africa against imperialism. It was therefore an event of singular political importance for white South Africans, but it was accomplished at the expense of South Africa's ignominious departure from the Commonwealth - of which General Smuts in the years before the Second World War had been its principal architect and protagonist. Smuts, the philosopher statesman, had propounded a philosophy of holism, in his book on the theory of Holism, ${ }^{79}$ which was reflected in his approach involving a philosophical and political synthesis - finding expression in the Commonwealth and also the League of Nations. ${ }^{80}$ South Africa's departure from the Commonwealth and the subsequent fragmentation of South Africa into Bantustans reflected the eclipse of this philosophy. The coming of the Republic was to herald South Africa's diplomatic and international isolation, for more than three decades ${ }^{81}$ However, it brought to an end the constitutional association with the United Kingdom and the Commonwealth, that had commenced on 16 September 1795 when the articles of capitulation were signed, and had only been interrupted once for three years by the Batavian interlude. ${ }^{82}$ Metaphorically, the apron strings were cut in a most traumatic manner - that led South Africa into international ostracism as a pariah $^{83}$ state, because of its policy of apartheid. Verloren van Themaat ${ }^{84}$ had pointed out earlier, in 1942, that it was accepted that self-governing dominions of the Commonwealth could unilaterally sever ties with the Commonwealth if so desired. In 1947, Burma was the first to exercise this option. ${ }^{85}$ This was to be followed by Ireland in 1949, when the Republic of Ireland came into being. ${ }^{86}$

Holism and Evolution (1926) at 353.

K Hancock Smuts 1: The Sanguine Years (1962) at 500-502.

See D Geldenhuys The Diplomacy of Isolation (1984). During the period 1961-1990, South Africa became increasingly isolated and ostracised, by virtue of the threat and subsequent application of economic sanctions, employment codes, and trade boycotts. See: TRH Davenport South Africa: $A$ Modern History (1987) at 489 et seq.

See: TRH Davenport South Africa: A Modern History (1987) at 41.

D Geldenhuys The Diplomacy of Isolation (1984) at 11. "An indication of the extent to which South Africa had become estranged from its traditional allies was when Britain, the United States and other Western countries declared their adherence to a voluntary arms embargo against South Africa called for by the UN Security Council in 1963".

M Wiechers Staatsreg (1981) at 132.

This was by virtue of the Burma Independence Act of 1947.

See: World Book Encyclopedia (1992), Vol. 19 at 337. In this regard, it is stated that "[i]n 1948 a coalition government under the Fine Gail leader John A Costello repealed the External Relations Act, severing the only remaining link between Britain and Eire. The Republic of Ireland was formally declared on April 18, 1949, and the Republic received international recognition”.

TD, 9(2), December 2013, pp. 309-340. 
No provision was made in the 1961 Constitution for a fundamental redistribution of power within the state. The Constitution therefore did not create a new basic norm or grundnorm $^{87}$ - which remained the sovereignty of the minority white South African parliament. The Westminster unitary system of government, which was retained, involved legislative sovereignty and a parliamentary executive. The Republican Constitution of 1961 terminated an era which had involved South Africa's emancipation from colonial tutelage by a process of incremental change and subsequent Commonwealth membership as a dominion - which started with the Union of South Africa, formed in 1910. This process was legitimate and had also occurred in relation to Australia, New Zealand and Canada. It was a genuine process of decolonisation, in which both General Smuts and Hertzog played significant roles, as explained above.

\section{Exclusion of People of Colour in the Constitutional Process of Emancipation}

The National Party government excluded all people of colour from any share in the making of the Republic. Dr Verwoerd decided that coloured voters would not be eligible to vote, but that the voters of South West Africa could indeed vote. Had the coloured voters been eligible to vote and the voters of the mandated territory of the erstwhile South West Africa been excluded, the republican majority may very well have been eliminated. ${ }^{88}$

At the time, in 1960, African leaders - including Nelson Mandela, as part of the National Action Council - called for a national convention of all races, coupled with a threat that if the government did not respond favourably, it would call a general strike between 29 and 31 May 1961, during the inauguration of the Republic. This was contemptuously spurned by the National Party government. ${ }^{89}$ More than three decades later, during which time Africa had experienced an historic process of decolonisation as explained below, with the unbanning of the liberation movements - Mandela and de Klerk were to play a vital role in both Codesa (akin to a national convention) and the Multi-Party Negotiation Process that followed. This, in turn, led to a historic political settlement, which paved the way for the Interim and final Constitutions of 1994 and 1996 respectively ${ }^{90}$ - which were both republican and democratic in character. Belatedly, South Africa was in a sense being 'decolonised' or liberated, and was metaphorically coming of age. Although South Africa's liberation was tragically and traumatically delayed, those who participated in the negotiating process and drafting of the two constitutions referred to above, were in a uniquely opportune position to learn from the African experience of decolonisation that had occurred in the previous decades since Harold MacMillan's epoch-making speech "Winds of Change" in 1960.

H Kelson General Theory of Law and State (1961) at 115: “A change of Grundnorm is by definition, an event outside and prior to law. It constitutes a technical revolution, for the Grundnorm embodies the identity of the state". See also: K Hancock Smuts 1: The Sanguine Years (1962) at 540. Jaarsveld and Scholtz (eds), Die Republiek van Suid-Afrika (1966) at 199 and 213 . 


\section{Process of internal decolonisation of Bantustans in South Africa ${ }^{91}$}

The practice and theory of territorial segregation had its roots in British colonial policy in the province of Natal. In fact, David Welsh, in his informative and scholarly book on the historical genesis of apartheid, ${ }^{92}$ comments that "it is a myth that apartheid is the exclusive product of Afrikaner Nationalism: its antecedents are to be found in Natal rather than any of the other provinces." The Lagden Native Commission (1903-1905) had created an influential blueprint for territorial segregation in order to halt land penetration by Africans, and had recommended that land for the ownership of Africans be demarcated by legislation. ${ }^{93}$ This was to find expression in the infamous Native Land Act of $1913,{ }^{94}$ which consolidated and legalised the practice of territorial separation, as expounded in the report of the Lagden Commission. The next important stage in this saga was the enactment of the Representation of Natives Act of $1936,{ }^{95}$ which introduced the principle of political segregation by abolishing the common-role franchise of the Cape Africans, and substituted in its place communal representation, and the ineffectual Native Representative Council. Africans and a small number of progressively-minded white persons strongly opposed this illiberal act of disenfranchisement. ${ }^{96}$ It was on the foundations of both territorial ${ }^{97}$ and political segregation, that the policy of internal decolonisation, involving unilateral partition, was to be built after the National Party victory at the polls in 1948.

The Native Administration Act of $1927^{98}$ was also a seminal piece of legislation, which was used to promote segregation and apartheid. It combined the Cape colonial technique of rule by proclamation, with the Natal doctrine of an absolute Supreme Chief - to produce a colonial-type structure of rule by the executive, acting through decrees of the GovernorGeneral. ${ }^{99}$ This formidable legislation, in effect gave the South African executive virtually unlimited power to legislate by proclamation in relation to African people - in effect, a Henry VIII clause involving very circumscribed judicial supervision.

See: GE Devenish Constitutional Change and Reform in South Africa, Doctoral Thesis, Unisa (1986) Chapt. 5. See also, in general, F Venter Die Suid-Afrikaanse Bantoe Staatsreg, Doctoral Thesis (1978).

The Roots of Segregation (1971) at 322.

E Hellman (ed.) Handbook on Race Relations in South Africa (1949) at 173.

27 of 1913.

Act 12 of 1936.

See T Karis and G Carter From Protest to Challenge (1979), Vol. 2, 4. See: TRH Davenport South Africa: A Modern History (1987) at 314. The most important of these was JH Hofmeyr, a cabinet minister from the United Party of Hertzog and Smuts.

The Land Act of 1913 scheduled about 7.5 percent of the country's land for Africans, which was increased to 13.7 percent by the Native Trust and Land Act 18 of 1936. T Karis and G Carter From Protest to Challenge (1979), Vol. 2, 4.

38 of 1927.

A Sachs Justice in South Africa (1973) 114.

TD, 9(2), December 2013, pp. 309-340. 
In May 1948, the National Party, with its policy of apartheid, came to power. An election pamphlet, issued by the National Party at the end of 1947, explained its policy and philosophy of "Bantu self-government", as follows:

The party is in favour of a system of local government for the Bantu more or less along the lines of the Bunga, which will uphold the authority of the tribal chiefs and enlist the services of educated Bantu. Such local councils are to be established in all the reserves with the prospect of developing into separate central councils for the different ethnic groups or sub-groups. ${ }^{100}$

Bantu self-government was the premise on which the policy of ethnic or domestic decolonisation was to be developed. The policy of apartheid - in relation to Africans envisaged the strengthening and restoration of the tribal system, and the re-establishment of the authority of the chiefs - which had been undermined by the urbanisation and consequent detribalisation of African people. The Bantu Authorities Act of $1951^{101}$ abolished the inoperative and ineffectual Native Representative Council, which was a western-styled, partly elected, and partly nominated advisory body. This seminal legislative enactment amounted euphemistically - in the words of Dr Verwoerd - to a restoration of "the natural Native democracy." ${ }^{102}$ The Act was intended to epitomise the positive aspects of the policy of apartheid, which in effect amounted to institutionalised racial discrimination in every sphere of society and government. The system of Bantu Authorities involved the replacement of western democratic principles in local government, by tribal principles in the native reserves. In the urban areas, Africans were merely to have the indefinite status of temporary sojourners.

\section{Nature and effect of Bantu authorities}

The Bantu Authorities Act removed the local franchise which had been exercised in the native reserves, and created a new dispensation, in which the chiefs - assisted by councillors would be appointed by the chief or headman, and not "as under the old Local Council system, by popular vote." 103 The political philosophy of this illiberal legislation, was explained as follows:

The idea is to foster strong progressive action by tribal authorities whose councillors should be able to act independently of a less progressive and probably dissatisfied electorate. ${ }^{104}$

The constitutionally-retrogressive nature of the Bantu Authorities was even more clearly spelled out in a handbook of the erstwhile Department of Native Affairs - explaining the

100 DJ Kruger SA Parties and Politics (1960) 406.

$101 \quad 68$ of 1951.

102 Hansard House of Assembly Debates (1951) col 9807. See also: H Kenney Architect of Apartheid H F VerwoerdAn Appraisal (1980) at 94.

103 Tomlinson Report (full report), chapt. 17, para 223.

104 Ibid. 
thinking behind the Act: "The councillors will perform their tasks without fear or prejudice because they are not elected by a majority of voters." ${ }^{105}$ The Act provided for a hierarchy of local authorities, consisting of tribal, regional and territorial authorities, and for the gradual delegation to these, of circumscribed executive and administrative powers, in their areas of jurisdiction. The Act also provided that after consultation with the people concerned, and with due regard to Bantu law and custom, the long-standing system of local councils might be replaced by Bantu Authorities.

African people were, however, deeply divided on the merits of the new system. Some traditional leaders and their followers welcomed the change, as they hoped it would reinforce and re-establish tribalism - which was in the process of inexorable disintegration - and thereby enhance the powers of the chiefs. Other traditional leaders, and most westernised urban Africans, were intensely critical, and they pointed out that, except in the Transkei to a limited extent, no provision was made for democratic principles in the constitution of Bantu Authorities. This was the very antithesis of western notions of constitutionalism and liberal reform. In essence, it constituted a subtle technique of divide and rule, involving the demarcation of African people into separate ethnic groups. Also, the system was essentially aristocratic, with the recognition of the chiefs as a core component. Patrick Lawrence - in his seminal study on South Africa's first nominally-independent Bantustan ${ }^{106}$ - stated:

It is clear that commoners will have little hope of electing representatives of their own onto the territorial authority. Individual commoners who are acceptable to the chiefs or department of Native Affairs may, however be appointed...

The institution of an 'aristocratic' form of local government for African people in the middle of the $20^{\text {th }}$ Century by a republican-inclined Afrikaner-Nationalist government, was anachronistic and anomalous. Furthermore, as indicated above, it involved the eclipse of the elective element in the erstwhile system of local and district councils.

The philosophy of apartheid was premised on the assumed irreconcilable cultural differences between whites and Africans. Democracy was seen to be exclusively a product of Western civilisation, and the tribal system was the corresponding indigenous equivalent for all Africans. What was required for Africans was, as indicated above, euphemistically termed "a natural African democracy." 107 This amounted in practice, in the form of Bantu Authorities, to a highly oligarchic system of local government, conceived by whites - according their preconceived ideas of tribal government. It also amounted to a system of indirect rule through the chiefs, which was not new, in that it had been used elsewhere in Africa. It had been employed extensively - and for a period successfully - in British colonial Africa. Lord Lugard, in his celebrated book The Dual Mandate in Tropical Africa, explained how it worked:

The essential feature of the system is that the native chiefs are constituted as an 'integral part of the machinery of the administration'.

In Natal, the influential 19th Century colonial administrator, Sir Theophilus Shepstone, used the same principle in native administration. ${ }^{108}$ However, indirect rule was eclipsed in the post

105 D Cowan Constitution Making for a Democrac, supplement to Optima, March 1960, fn 23 at 1.

106 Transkei, the Politics of Partition (1976) at 26.

107 See: H Kenney Architect of Apartheid H F Verwoerd - An Appraisal (1980) at 94.

108 D Welsh 'Chieftanship under Shepstone'. In: The Roots of Segregation (1971), Chapt. 7. 
Second World War era in the British colonies - by the inexorable demand for western-styled representative institutions. However, when indirect rule was on the wane in the British colonial empire, it was belatedly introduced in South Africa. Lord Hailey therefore perceptively commented in his magisterial work, African Survey: A Study of Problems Arising in Africa South of the Sahara, ${ }^{109}$ as follows:

But the recent decision to improve the status of chiefs or to base the institutions of local government on Tribal Councils rather than on electoral bodies belongs to a different category. It is an attempt to divert attention of the African from a pattern which is favoured by Europeans and in which he might desire to share. The change of policy embodied in this decision has been made at a time when most of the British and French dependencies the African is being given increasing access to institutions of a European pattern. The forces of traditionalism are still strong in Africa, and it is possible that the changes may have attractions for some part of the African population in the Union, it is not likely to appeal to the growing body of more progressive Africans or to the great mass of those who now live in urban conditions. For them it can have little or no meaning, and it is to this class that African society now looks for its leaders. ${ }^{110}$

Furthermore, when indirect rule was introduced into Nigeria, Tanganyika and Northern Rhodesia, ${ }^{111}$ indigenous tribal life was virtually unimpaired. It had not been emaciated by an economic and industrial revolution, as had occurred as a result of the European exploitation of mineral resources and the consequent urbanisation and detribalisation of African people in South Africa. In British colonial Africa, indirect rule was used to train African people in local government in order to equip them to participate, ultimately, at the central level of government. In South Africa, the rejuvenation of tribal government, however, was intended to be a surrogate for participation at the central level of government. Marquard explained this by commenting that " $[\mathrm{u}]$ nder indirect rule in British colonies, tribalism is made a temporary transitional purpose. Under the National Party policy it becomes an end in itself." 112 With regard to the policy of separate development, the system of Bantu Authorities was of seminal importance. It was to lay the foundation for the unilateral partitioning of South Africa. Lawrence aptly commented that "[ $t]$ he process of implementing the grand design of separate development began with the Bantu Authorities Act which Verwoerd put through parliament in $1951^{\prime \prime} .113$

\section{The Promotion of Bantu Self-Government Act ${ }^{114}$}

\section{$109 \quad$ (1956) 343.}

110 Ibid.

111 Lord Hailey African Survey: A Study of Problems Arising in Africa South of the Sahara (1956) at 202. See also: L Marquard The People and Policies of South Africa (1960) at 107.

112 L Marquard The People and Policies of South Africa (1960) at 107.

113 See P Lawrence Transkei, the Politics of Partition (1976) at 59.

114 Act 46 of 1959 
This was the next legislative step in the process of internal decolonisation. This legislation abolished the parliamentary representation of Africans in the Cape Province - who had enjoyed common-roll franchise rights in the Cape Colony from the inception of representative government in 1853, and also subsequent communal representation in the Union of South Africa from 1936 to 1960. It was another inexorable step in the process of disenfranchisement and constitutional retrogression of persons of colour. This had started with the Representation of Natives Act of $1936,{ }^{115}$ which introduced the principle of political segregation by removing the common roll franchise for Cape Africans, and substituting in its place communal representation. Africans strongly opposed this act of disenfranchisement. In the words of Karis and Carter: "African reaction was unequivocal in its opposition and Union wide in its expression." ${ }^{116}$

Legalised fragmentation and segregation were the very antithesis of the ideas and policies of inclusion of persons of colour in the body politic of South Africa, and which found expression in the Cape's liberal tradition. These ideas and policies were to be inexorably eclipsed by the policies of disenfranchisement, segregation, and ultimately apartheid. African and coloured persons respectively were disenfranchised in 1936 and 1956. The disenfranchisement of the coloured persons on the common role in the Cape Province involved a battle lasting four years - from 1952 to $1956 .{ }^{117}$ At the heart of this constitutional struggle and crisis was the constitutional significance of the entrenched provisions of the South Africa Act, and the nature of parliamentary sovereignty provided for in this Constitution. Segregation and apartheid involved, inter alia, a retrogressive disenfranchisement of people of colour from the common roll. This is the antithesis of what occurred in Great Britain - where an incremental process involved the progressive enfranchisement of the population, and starting with the great Reform Act of 1832. This process in Britain culminated in universal adult franchise in 1930, when women exercised the vote on the same basis as men. ${ }^{118}$

The Bantu Authorities Act recognised eight African national units, based on ethnic considerations, and provided for the appointment of five Commissioners-General to represent the government in these areas. The preamble to the Act endorsed the thinking of divide and rule, by stating: "The Bantu peoples do not constitute a homogeneous people, but form separate national units on the basis of language and culture."119

At the time, it was not entirely clear what the ultimate destiny of the national units would be. The White Paper ${ }^{120}$ accompanying the Bill spoke of its intention to create "self-governing units" and of "creative self-withdrawal" by the European guardian. In order to justify the "concurrent abolition of the Native Representation in Parliament", it drew an analogy with

$115 \quad 18$ of 1936.

116 See T Karis and G Carter From Protest to Challenge (1979), Vol. 2, 4.

117 This involved the famous Harris cases, and Collins $v$ Minister of the Interior (1957) (1) SA 552.

118 See J Harvey and L Bather ‘The Reform of the Electoral System’ In: The British Constitution (1968) at 49 et seq.

119 In this regard, D Geldenhuys The Diplomacy of Isolation (1984) at 11, comments that "It was the first time that territorial separation was legislatively explicitly linked to ethnic separation”. 
the Commonwealth - in which none of its dependent or component territories had direct representation in the parliament of the United Kingdom before gaining independence. Furthermore, it was within the bounds of possibility that the Bantu national units might ultimately become completely independent, as was indeed to occur in relation to Transkei, Bophuthatswana, Venda and Ciskei. In this regard, Dr Verwoerd was reported as saying in parliament that "I foresee that - the eventual outcome of this policy will be no discrimination and no domination." ${ }^{21}$ What was foreseen was a South African "Commonwealth," with the "white" South African state serving as its core, and being the ultimate guardian of the emerging Bantu states. This would have involved partition, giving rise to a confederation or constellation of states. It must be noted that partition had from time to time received some support from persons of liberal disposition, such as the erudite Prof RF Hoernle, a well known South African liberal who considered that total segregation or partition offered a just solution to South Africa's political problems. This was the opinion expressed in a book The South African Native Policy and the Liberal Spirit. ${ }^{122}$ As a result, Lever commented that "[t]he idea of separation as a solution to South Africa's race problems has an appeal on the left as well as the right of the political spectrum." 123 Obviously what these liberals had in mind was a bilateral negotiated process of partition, and not the unilaterally conceived and imposed one devised by Dr Verwoerd and the National Party government.

\section{A fundamental change of policy}

The year 1959 was a decisive watershed in the evolution of the policy of so called 'grand' apartheid. In this year, Dr Verwoerd, the erstwhile South African Prime Minister, had come to realize that the growing criticism of apartheid abroad demanded changes which would give some moral basis to the policy of separate development - "however specious and expedient it may seem to critics." 124 Dr Verwoerd's own words support this contention: “... we cannot govern without taking into account the tendencies of the world and in Africa. We must have regard to them. Our policy must take them into account." ${ }^{25}$ Dr Verwoerd endeavoured to resolve the fundamental constitutional and political problem facing South Africa with a stratagem of unilateral partition. In so doing, he rejected a liberal policy of constitutional reform involving the extension of the franchise to African people, within a united South Africa.

As explained above, the European colonial powers were, in 1959, in the process of embarking on a policy of decolonisation that was to lead to the independence of colonial territories. It was this emancipation from colonial rule in the "world and in Africa" that had to be taken into account. However, the National Party - during its first decade of rule after its election victory in 1948 - had been vociferously critical of the liberal colonial policies of the British

121 Hansard Debates of the House of Assembly col 4552, 14 April 1961.

122 At 183

123 H Lever South African Society (1978) at 265.

124 H Kenney Architect of Apartheid H F Verwoerd - An Appraisal (1980) at 55.

125 Ibid. 
government, which preceded independence. ${ }^{126}$ Although Dr Verwoerd's new policy of proposed sovereign independence for the erstwhile native reserves was innovative, its potential for constitutional reform was controversial and highly ambivalent.

In 1960, in the wake of the tragic Sharpeville massacre, the ANC and the PAC were banned. ${ }^{127}$ This was to force African people to channel their political activities and aspirations into homeland political institutions, or to opt for illegal revolutionary political activity - since it had become increasingly difficult for Africans to advocate and work for a genuine nonracial democratic system of government. This became virtually impossible after the enactment of the Prohibition of Political Interference Act in 1968. ${ }^{128}$

\section{Subsequent constitutional development}

The implementation of the Bantu Authorities Act set in motion a process that began to gather its own momentum and initiative. By March 1960, there were 371 tribal authorities, 29 regional authorities, and only one territorial authority. ${ }^{129}$ In 1961, Ciskeian and Tswana Territorial Authorities were, however, established. ${ }^{130}$ In January 1962, Dr Verwoerd made a historic announcement that Transkei was to be granted self-government. ${ }^{131}$ This was preceded by a motion introduced in the Transkeian Territorial Authority - requesting the government to declare the Transkei a self-governing state under black control. ${ }^{132}$ Similar motions had been put to the Bunga in 1944 and $1946 .{ }^{133}$ They were rejected on both occasions. This meant that - independent of the National Party's policy of separate development - the Transkei had a history of endeavours to acquire a form of selfgovernment, dating back to the war years and the Smuts government. This urge for selfgovernment was skilfully used by the National Party to promote its policy of unilateral partition.

Self-government for Transkei was an important and pioneering step in the process of internal decolonisation and constitutional 'reform', according to the philosophy of apartheid. Furthermore, the National Party government was embarking on a process that would be difficult - if not impossible - to reverse, and was to culminate in 'independence' for Transkei.

126 D Geldenhuys The Diplomacy of Isolation (1984) at 13, who comments that "This found clear expression in Malan's Africa Charter, an anachronistic statement of policy aimed at stemming the tide of decolonization".

127 See, in general, T Lodge Sharpville (2011).

12851 of 1968. See: Annual Survey of South African Law (1968) at 2.

129 Rand Daily Mail, 9 March 1960.

130 GN No R 496, GGN No 6656 of 24 March 1961, and GN No 585, GG No 6666 of 21 April 1961.

131 Hansard House of Assembly Debates vol 2 cols 75 ff (23 January 1962). See: Annual Survey of South African Law (1962) at 61.

132 P Lawrence Transkei, the Politics of Partition (1976) at 25.

133 Made by Councillor Lingham Maninjwa. See DA Kotze African Politics in South Africa (1964-1974) at 27-28. 
Although, in terms of the Transkei Constitution Act, ${ }^{134}$ the African parts of Transkei became a separate territory, it did not create a federation or an independent state. The attitude of the South African government was that nationhood must precede statehood. ${ }^{135}$ The relationship between the Transkei and the central government of the Republic was sui generis. There was no comparable analogue. ${ }^{136}$ The policy of apartheid required that Africans in the homelands be 'liberated' from tutelage, as members of ethnic units. This putative method of reform was intended to ensure coexistence between whites and blacks. Genuine reform within a unitary or even a federal state would, according to the protagonists of separate development, result in black majority rule - which at the time was unthinkable for the National Party of Dr Verwoerd.

The self-governing Transkei was the first fruit of a self-induced internal decolonisation movement, that was to result in constitutional balkanisation. The Constitution of Transkei was partly 'aristocratic', since it entrenched the power of the chiefs. Although all adult citizens qualified for the franchise, 64 chiefs ex officio were appointed to the legislature, in which there were only 45 elected members. This meant that the elected element was introduced, but only in an attenuated form. ${ }^{137}$ Nevertheless, in so doing, Dr Verwoerd took a calculated risk that the political forces unleashed by self-government could be contained within the framework of his rigidly-conceived policy of apartheid. ${ }^{138}$ This is clearly evident from the first election that occurred in the Transkei. There were no political parties as such, and, as a result, the voters had to choose between competing and opposing political philosophies. Chiefs Victor Poto and Kaiser Matanzima emerged as advocates of multiracialism and separate development respectively. Of the successful candidates, Poto claimed 38 of a total of 45 who were aligned with him, and Matanzima reportedly conceded 35. ${ }^{3} 9$ This meant that 64 ex officio chiefs held the key to power. They voted overwhelmingly for Chief Matanzima, who, as a result - by means of a narrow majority of 54 to 49 - was elected as Chief Minister of Transkei. Although the gamble had paid off, it was clear that the majority of voters of Transkei were strongly opposed to the policy of separate development, and by supporting Chief Poto had expressed a preference for multi-racialism within a single South African state. Besides the legislature, provision was also made for an executive

13448 of 1963. See: E Kahn "Some thoughts on the Competency of the Transkeian Legislative Assembly and the Sovereignty of the South African Parliament" SALJ (1963) at 61.

135 E Kahn Annual Survey of South African Law (1963) at 56.

136 Ibid.

137 See: H Kenney Architect of Apartheid H F Verwoerd - An Appraisal (1980) at 232, who states "in fairness to Verwoerd it must be pointed out that this closely resembled the official majorities in the British and French colonies in the early 1950's: it could be seen as only the first stage in an inevitable unfolding process of emancipation." This transpired to be the position in retrospect, except that the South African process of decolonisation was to take much longer than that of the British or French.

138 The self-governing Constitution of Transkei can be viewed as an endeavour to reconcile the conflicting aspirations of the traditionalists - i.e. the indigenous leaders - with the modernists in African society, in order to produce a politically stable system. 
authority, comprised of a Chief Minister and 6 other ministers, and ultimately for the introduction of a High Court. ${ }^{140}$

With the enactment of the Bantu Constitution Act, ${ }^{141}$ certain other ethnic units began to embark on the path of self-government. In 1973, it was the turn of Venda, Gazankulu and KwaZulu, and Qwaqua followed in 1974. ${ }^{142}$ This was followed by the implementation of the Bantu Homelands Citizenship Act, ${ }^{143}$ which provided that every African person in the Republic of South Africa was to be a citizen of one or other territorial area. Such persons were, however, to retain their South African citizenship, and this was to lead to a form of dual citizenship. It was an important preparatory step in the very controversial process of 'denationalising' millions of African people. ${ }^{144}$ It was to apply to all African people, including those who had lived in the urban areas for generations, and who had no real contact with homeland areas. The constitutional development in KwaZulu was particularly slow - because the Zulu leaders and particularly Chief Buthelezi, ${ }^{145}$ considered that the Bantu authorities offered no lasting solution to South Africa's complex racial and political problems. Considerations of Real politik, however, forced the Zulus into reluctant acceptance. ${ }^{146}$

\section{Consummation of the policy of internal decolonisation}

The policy of so-called grand apartheid, was to be consummated in the establishment of the so-called 'independent' Bantustans, such as Transkei, Ciskei, Bophuthatswana and Venda all of whom were granted a form of putative independence in the years following the advent of the Republic. None of them were to be accorded international recognition - being perceived as a product of the infamous policy of apartheid. Nevertheless, in a very real manner, the metaphorical apron strings were cut by the respective Status Acts, for the states concerned. In a technical sense, a revolution had indeed occurred, ${ }^{147}$ since in each case the

140 Section 50. This belatedly came into operation from 1 August 1973 - by virtue of a proclamation. See: Annual Survey of South African Law (1973) at 32. This was another important milestone in the unfolding of the process of emancipation leading to decolonisation, since it provided for a separate judiciary - the third arm of government.

14121 of 1971.

142 Gov Notices: Venda 12 of 1973; Gazankulu 14 of 1973; KwaZulu 69 of 1973 and 223 of 1976; and Quaqua 112 of 1974.

14326 of 1970.

144 See J Dugard 'The Denationalisation of Black South Africans: A question for the International Court of Justice" Lawyers for Human Rights, Bulletin no. 4 (1984) at 11.

145 See: J Butler The Black Homelands of South Africa at 40, who comments that "Zululand (since 1972 known as Kwa-Zulu), although the most populous of the homelands, was loath to co-operate with the wishes of the Department of Bantu Administration ... The delay in achieving self-government in KwaZulu has been due in part to the political struggle between Buthelezi and the central government".

146 See: M Horrell Laws Affecting Race Relations in South Africa at 42, who comments that "[a]ccording to press speculation, the reason was that they found themselves excluded from economic progress and political advances being made elsewhere, had little responsibility for their own affairs, and lacked a platform from which to express their views".

147 See HR Hahlo and E Kahn The Union of South Africa: The Development of its Laws and Constitution (1960) at 150 .

TD, 9(2), December 2013, pp. 309-340. 
locus of sovereignty shifted irrevocably from the Republican parliament, to the new state concerned - analogous to what had occurred to the erstwhile Union of South Africa in terms of the Statute of Westminster and the Status Act of $1934 .{ }^{148}$

Sovereign independence for these states was not the end of the road. In a paradoxical way, the ethnic fragmentation of South Africa was an anomalous stage in the circuitous process of economic and political re-integration into the body politic of a greater South Africa. Unrest and instability in these territories contributed to the incipient and potential insurrection that gathered momentum in South Africa in the 1980s, and which could only be contained by successive states of emergencies - commencing in $1985 .{ }^{149}$

The 1960s had par excellence been one of decolonisation for Africa. British Prime Minister, Harold Macmillan's epoch making "Winds of Change" speech, made in Cape Town in $1960,{ }^{150}$ had profound political influence on the course of decolonisation - in both Africa as a whole, and in South Africa. As a result, during the 1970s, the National Party government began to endeavour in its own unique way, to emulate this process of decolonisation. This involved fundamental constitutional and political changes, but these were imposed by an oligarchic white government on indigenous black people. It was not a process that had been worked out and negotiated by legitimate representatives of both the white and black populations. Its continued application depended on coercion, and, in its unfolding, frequent inroads were made into the norms of constitutionalism and democratic government - always by recourse to African law and practice of indigenous rule, as perceived by whites. It was not a genuine process of decolonisation, but rather a putative or pseudo one, or one which had the "goal of co-opting a trained indigenous social class into a political framework" ${ }^{151}$

The process of integration, de-integration and re-integration of the territories that made up South Africa, can be compared with the fate of Yugoslavia during the $20^{\text {th }}$ Century. ${ }^{152}$ As indicated above, the Union brought together the four erstwhile British colonies in 1910. Thereafter, application of the policy of apartheid fragmented South Africa into selfgoverning and independent homelands. Finally, the process of negotiation leading to the interim and final 1996 Constitution, resulted in the re-integration of these homelands. As far as Yugoslavia is concerned, the name "describes three political entities that existed at one time on the Balkan Peninsula in Europe during most of the twentieth century" ${ }^{153}$ Firstly, the Kingdom of Serbs, Croats and Slovenes was a monarchy formed after the First world War on 1 December 1918, and was renamed Yugoslavia by King Alexander 1 on 6 January 1929. Secondly, Yugoslavia, which existed under various designations and was the successor to the Kingdom, was called, inter alia, the Socialist Federal Republic of Yugoslavia, but disintegrated as a result of the collapse of the Soviet Union in the early 1990s. Finally, there was the Federal Republic of Yugoslavia, which existed from 1992 to 2003, and consisted of

148 See no 69 of 1934.

149 See: Race Relations Survey 1985 at 28.

150 See: G Wasserman Politics of Decolonization (1976) at 8.

151 Idem at 11.

152 'Yugoslavia', available at: http://en.wikipedia.org/wiki/Yugoslavia, at 1.

153 New World Encyclopedia, available at: http:/www.newworldencyclodedia.org/entry/Yogoslavia, at 1. 
Serbia $^{154}$ and Montenegro. The latter states declared their independence on 3 and 5 June 2006 respectively, and constituted the last remnants of the Federation of Yugoslavia. ${ }^{155}$

\section{Role of the liberation movements}

In 1912, two years after the formation of the Union of South Africa, the ANC was formed. It was convened by two prominent African lawyers, PK Seme and RW Msimang - who were also responsible for drafting its constitution. ${ }^{156}$ In the 1920s and 1930s, its moderate leaders attempted, to little avail, to engage successive white governments to respond positively to the reasonable aspirations of African people. It policy of moderation bore little fruit. During the Second World War, however, the ANC became a manifestly more militant political organisation, as a result of the activities of its Youth League, involving, inter alia, Nelson Mandela, Walter Sisulu and Oliver Tambo. ${ }^{157}$ As a consequence of the Atlantic Charter accepted by the Allied Powers during the Second World War - African leaders in South Africa drafted a monograph entitled "The African Charter from the African's point of view". This was followed by the "Bill of Rights", drawn up by a committee of African leaders, and adopted by the ANC in December 1943. ${ }^{158}$ After the war, the ANC and the Natal Indian Congress were involved in a heroic defiance campaign in the early 1950s, ${ }^{159}$ and in 1956 it drafted the legendary Freedom Charter. ${ }^{160}$ In 1960, as a result of the disturbances that culminated in the tragic massacre at Sharpeville, the ANC, PAC and South African Communist Party, were declared unlawful organisations by the National Party government, and were banned. As a result, members were forced into exile ${ }^{161}$ and sought liberation by revolutionary means.

The exclusion of African people from political participation in the political structures of South Africa gave rise to intense dissatisfaction, alienation and serious violence from time to time. The tragic Sharpeville massacre and the Soweto riots of 1976, are notorious examples in this regard. The ANC, PAC and South African Communist Party had now become liberation and revolutionary movements, proscribed in South Africa. From 1985 onwards, a virtually continuous and brutal state of emergency was instituted in order to deal with the seething and incipient rebellion in the African townships of South Africa. This turbulent era, encapsulated the ill-fated Tri-Cameral Constitution of 1984 - involving whites, coloureds and Indians, but excluding Africans. This period was characterised by the "Imperial

154 Serbia included the autonomous provinces of Vojvodina, Kosovo and Metohija.See: New World Encyclopedia, available at: http:/www.newworldencyclodedia.org/entry/Yogoslavia, at 1.

155 http://en.wikipedia.org/wiki/Yugoslavia, at 1.

156 A Sachs Justice in South Africa (1973) 210.

157 M Wilson and L Thompson (eds) The Oxford History of South Africa (1978) at 458.

158 Idem at 456.

159 T Lodge Black Politics in South Africa since 1945 (1990) at 42-45.

160 Idem at 71-4.

161 Idem, chapt. 10, 'Guerillas and insurrectionists, 1961-1965'.

TD, 9(2), December 2013, pp. 309-340. 
Presidency" of Mr P W Botha, ${ }^{162}$ whose administration governed by increasingly dictatorial methods, in terms of emergency regulations. Apartheid and white minority rule involved a notorious assault on human rights ${ }^{163}$ and inordinate suffering and tribulation for the Black people of South Africa.

\section{Decolonisation in Africa ${ }^{164}$}

During the historic "Scramble for Africa", ${ }^{165}$ which took place between 1876 to 1912, the European powers demarcated Africa and its rich resources at the Berlin Conference of 188485. ${ }^{166}$ In this regard, although Britain and France obtained the lion's share, Germany, Spain, Italy, Belgium and Portugal also obtained colonies. This was morally and politically justified "using the concept of the White Man's burden, (and) an obligation to 'civilize' the people of Africa". ${ }^{167}$ As a result, the vast resources of the African continent were ruthlessly exploited, although the Second World War and the adoption of the Atlantic Charter led to decolonisation becoming inevitable, first in Asia, and then in Africa.

Decolonisation was to take place during the era of the Cold War, which was to have an important influence - clearly reflected in the "Winds of Change" address to the South African parliament in 1960. In it, the British Prime Minister stated that " $[t]$ he growth of national consciousness in Africa is a political fact and we must accept it as such ... I believe that if we cannot do so we may imperil the precarious balance between East and West and on which the peace of the world depends". ${ }^{168}$ Decolonisation proved to be problematic due, inter alia, to the fact that the indigenous population were ill prepared by their colonial masters to assume power and the responsibilities of government. So, for instance, even after the war, the British still considered "their African colonies as 'children' and 'immature'; and they introduced democratic government only at local levels". ${ }^{169}$

During the 1930s, however, the Western colonial powers educated a small elite of indigenous leaders at their universities - where they imbibed liberal ideas of government such as government by consent, the rule of law, and individual rights. These leaders - such as Kwame Nkrumah and Jomo Kenyatta - were to play a pivotal role in the struggle for independence and subsequently statehood. However, the pitiful record of many post-independent Africa states has produced harsh criticism, given that the decolonisation process between 1950-1970 resulted in regimes that were characterised by violence, inefficiency, nepotism and corruption, and which were the very antithesis of the rule of law and human rights. ${ }^{170}$ As a result, the question must be asked: who really benefitted from the political exercise of decolonization? In

162 See, in general, B Pottinger The Imperial Presidency (1988).

163 See, in general, J Dugard Human Rights and the South African Legal Order (1978).

164 See, in general, D Birmingham The Decolonization of Africa (1995).

165 See: T Pakenham The Scramble for Africa (1992).

166 See: 'Decolonisation of Africa', available at: http://en.wikipedia.org/wiki/Deloniztion_of_Africa at 1 (Accessed 30 July 2013)

167 Ibid.

168 B Talton 'The Challenge of Decolonization in Africa', available at: http://exhibitions.nypl.org/africanaage/essay-challenge-of-decolonization-africa.html.

169 See: T Pakenham The Scramble for Africa (1992).

170 This is a common point of view that found expression in a BBC News Broadcast, 22 September 2004: 'Africa better in colonial times'. 
the 1960s, Frantz Fanon, the revisionist intellectual, commented on neo-colonialism, that "because it proposes to do justice to human dignity in general, addresses itself essentially to the middle classes and the intellectuals of the colonial country", and that this resulted in "the continued exploitation of the continent from outside and within, together with European political intervention during the post-independence years". ${ }^{171}$ As a consequence, he argues that this state of affairs benefitted African politicians and a small middle class, but not the vast majority of ordinary people in these states. ${ }^{172}$ This produced political instability, which facilitated insurrection and coup d'etats. The instability that occurred in the nominallyindependent Bantustans in the 1980s, is analogous with Fannon's sentiments.

\section{Conclusion}

The constitutional and political dilemma of South Africa was how to effect reform and maintain "civilised" values in a body politic, in such a manner that minorities are protected, justice is done to the majority, and simultaneously one group is prevented from exercising domination over any other group. Apartheid was morally and politically not the answer to this question. The resignation of the ailing President PW Botha in 1989 and the election of Mr FW de Klerk as President, was providentially to usher in a new era for South Africa. In a watershed speech to the South African parliament on 2 February 1990, Mr de Klerk announced the unbanning of the liberation movements - ANC, PAC, and the South African Communist Party - and the release of political prisoners such as Nelson Mandela, who, behind the scenes, had played a seminal and decisive role in facilitating political reconciliation. This paved the way for the process of genuine political negotiation between the major and lesser political role players in South Africa. This took place within the framework of the Convention for a Democratic South Africa (CODESA) - created for this purpose. CODESA drafted a declaration of intent, in which the signatories committed themselves to the drafting of a new constitution for South Africa, as soon as possible.

Only with the inception of the Interim Constitution, following the first historic democratic election of 27 April 1994, did South Africa and its people adopt an authentic democratic and republican Constitution. This was effected within a unified framework, involving an entrenched Bill of Rights, with a democratically elected government, in an exemplary and consolidated Republic - respected worldwide and premised on government by consent, guaranteed by universal adult suffrage. Involved in this process was the re-incorporation of the putatively independent territories of Transkei, Bophuthatswana, Venda and Ciskei which constituted a categorical repudiation of the pseudo decolonisation that had created "independent Bantustans". However, in an ironic way, it constituted another unique aspect of decolonisation in the broadest sense of the word.

After an absence of more than three decades, during which time the indigenous people of South Africa were subject to inordinate suffering and oppression, flowing from institutionalised racial nationalism - South Africa was to emerge liberated, as a fully -ledged, non-racial democracy, and with a state-of-the-art Constitution, admired by all. As a result, South Africa was readmitted to the Commonwealth of Nations, with open arms. As indicated above, General Smuts had previously played a decisive role in the conception and 
establishment of the Commonwealth, in the years before the Second World War, ${ }^{173}$ and from which South Africa departed so ingloriously as a consequence of Dr Verwoerd's policy of apartheid. ${ }^{174} \mathrm{Re}$-admission therefore meant the wheel has indeed come full circle. At long last, after much travail, South Africa was on a path that was morally and politically defensible - to facilitating a just society for all its people within the framework of an inclusive, nonracial liberal democracy, and as a respected and valued member of the Commonwealth and the United Nations. At long last, liberal democracy had triumphed over racial nationalism.

There are lessons to be learned from South Africa's traumatic and tragic experience with Bantustan decolonisation, inter alia, in countries where there was some form of partition such as Palestine, ${ }^{175}$ Northern Ireland, and Cyprus. The political conundrum relating to the Palestinian people and the prospective independence of Palestine, is one of the unresolved issues of decolonisation which arose out of the independence of Israel in $1948 .{ }^{176}$ On 29 November 2012, the United Nations General Assembly, in a vote of 138 to 9, and by means of Resolution 177, upgraded Palestine to a "non-member observer state" status at the United Nations. This new status equates Palestine with that of the Holy See - the Vatican. ${ }^{178}$ By April 2013, 132 (68.4\%) of the 193 member states of the United Nations have in fact recognised the State of Palestine. Indeed, the present condition of Palestine and its people represents the unfinished business of decolonisation in this part of the world. It remains to be seen whether, in the long term, a two state ${ }^{179}$ or one state scenario will emerge from the present uneasy and turbulent state of affairs in the Middle East.

\section{Bibiography}

Annual Survey of South African Law (1959), Juta \& Co, Cape Town.

Annual Survey of South African Law (1962), Juta \& Co, Cape Town.

Annual Survey of South African Law (1963) Juta \& Co, Cape Town.

Annual Survey of South African Law (1973) Juta \& Co, Cape Town.

173 K Hancock Smuts 1: The Sanguine Years (1962) at 429.

174 Although this was a disaster for South Africa, according to D Geldenhuys The Diplomacy of Isolation (1984) at : "For some of the more ardent republicans in the National Party it was an added bonus that the new Republic was outside the Commonwealth."

175 See: A Sampson The Anatomist (2008) at 255: "Like many black South Africans, he (Mandela) saw parallels between the Israeli occupation and the apartheid government's domination of the Bantustans." See also: http://en.wikipedia.org/wiki/Two state solution.

176 This occurred less than a year after the British government withdrew from the Palestine Mandate - set up after the First World War, and administered by the League of Nations.

177 Resolution 67/19.

178 See: "State of Palestine", Wikipedia Encyclopedia, available at: http://wikipedia.org/wiki/State of Palestine, at 2. (Accessed on 30 July 2013)

179 See: http://en.wikipedia.org/wiki/Two state solution.(Accessed on 30 July 2013). 
Birmingham D The Decolonization of Africa (1995),University College London Press, London.

Butler J The Black Homelands of South Africa (1977), University of California Press, Berkley.

Chamberlain M E Decolonization: The Fall of European Empires (1987), Basil Blackwell, Oxford.

Cole J "Decolonization”, International Encyclopedia of the Social Sciences, available at: http://www.encyclopdia com/topic/Decolonization.aspx, at 5. (Accessed 27 July 2013).

Coertze GA "Die Wetgewende Orgaan van die Unie van Suid-Afrika" THRHR (1941) at 53, and by the same author 'Die posisie van die Koning as Hoof van die Uitvoerende Gesag van die Unie van Suid-Afrika' THRHR (1939) at 250, Butterworths, Durban.

Cowan DV “The Legislature and the Judiciary" Modern Law Review 15 (1952) at 294, John Wiley \& sons, London.

Cowan DV “Constitution Making for a Democracy”, Supplement to Optima, March 1960, Anglo-American Corporation, Johannesburg.

Davenport T R H South Africa: A Modern History (1987), MacMillan South Africa, Johannesburg.

Dawson R M The Development of Dominion Status 1900-1936 (1965), Frank Cass, London.

"Decolonization of Africa", available at: http://en.wikipedia.org/wiki/Delonization_of_Africa at 1 (Accessed 30 July 2013).

Devenish G E Constitutional Change and Reform in South Africa, Doctoral Thesis, (1986) Unisa, Pretoria.

Devenish G E "South Africa from pre-colonial times to democracy: A constitutional and jurisprudential odyssey” TSAR (2005), Juta \& Co, Cape Town at 553.

Dugard J "The Denationalisation of Black South Africans: A question for the International Court of Justice" Lawyers for Human Rights, Bulletin no. 4 Juta \& Co, Cape Town, (1984) at 11.

Encyclopaedia Britannica, 1993, volume 18, University of Chicago, Chicago.

Fanon F O The Wretched of the Earth (1990), Penguin Books, London.

Fanon F O Towards the African Revolution (1964) Writers and Readers Publishing Cooperation, New York.

Geldenhuys D The Diplomacy of Isolation (1984) MacMillan South Africa, Johannesburg.

Hahlo HR and Kahn E The Union of South Africa: The Development of its Laws and Constitution (1960), Juta \& Co, Cape Town.

Hailey Lord M African Survey: A Study of Problems Arising in Africa South of the Sahara, (1938), Oxford University Press.

Hancock K Survey of British Commonwealth Affairs (1918-1939) (1942), Vol. 1, Oxford University Press, London.

Hancock K Smuts 1: The Sanguine Years (1968), Cambridge University Press, Cambridge. 
Harvey J and Bather L "The Reform of the Electoral System" in: The British Constitution and Politics,(1982) MacMillan Educational, London.

Horrell M Laws Affecting Race Relations in South Africa (1978) South African Institute of Race Relations, Johannesburg.

http://en.wikipedia.org/org/wiki/Burma\#History. (Accessed on 30 July 2013).

http://en.wikipedia.org/org/wiki/Burma\#History. (Accessed on 30 July 2013).

http://national history centre. Org/tag/decolonization/. Accessed on 27 July 2013.

http://en.wikipedia.org/wiki/Southern-sudan, at 1.(Accessed 29 July 2013).

http://www.huffingtopost.com/tag/decolonization. (Accessed on 27 July 2013).

http://www.credoreference.com/topic/decolonization, at 1. (Assessed 27 July 2013

http://en.wikipedia.org/wiki/Delonization, at 2. (Accessed on 29 July 2013).

http://en.wikipedia.org/org/wiki/Burma\#History. (Accessed on 30 July 2013).

http://en.wikipedia.org/wiki/Two state solution. (accessed on 30 July 2013).

Kahn E "Some thoughts on the Competency of the Transkeian Legislative Assembly and the

Sovereignty of the South African Parliament" South African Law Journal, (1963) Juta \& Co, Cape Town.

Karis T and Carter G From Protest to Challenge (1978), volume 2, Hoover Institute Press, Stanford, Vol. 2

Keith A B The Dominions as Sovereign States (1938),Macmillan \& Co, London.

Keith A B Responsible Government in the Dominions (1930), Macmillan \& Co, London.

Kelly J M The Irish Constitution (1984), Jurist Publishing Co, University College, Dublin.

Kelson H General Theory of Law and State (1961), translation by A Wedberg, Russell \& Russell, New York.

Kenney H Architect of Apartheid H F Verwoerd -An Appraisal (1980), Jonathan Ball, Cape Town.

Kruger DJ SA Parties and Politics (1960), Herman and Rousseau, Cape Town.

Lodge T Black Politics in South Africa since 1945 (1983) Ravan Press, Johannesburg.

Lodge T Sharpville (2011) Oxford University Press, Oxford.

Lane P H Lane's Commentary on the Australian Constitution (1996), The Law Book Company, Sydney.

Lever H South African Society (1978), Jonathan Ball, Johannesburg.

Lawrence P Transkei, the Politics of Partition (1976) Ravan Press, Johannesburg.

Lugard Lord F The Dual Mandate in Tropical Africa, Frank Cass, London,1965.

Lukas C P Lord Durham's Report, Vol. 2, (1912), Oxford University Press, Oxford.

Mansergh N Survey of British Commonwealth Affairs (1939-1952) (1958), Oxford University Press, London.

Marquard L The People and Policies of South Africa (1960), Oxford University Press, Oxford. 
New World Encyclopedia, available at: http:/www.newworldencyclodedia.org/entry/Yogoslavia, at 1.

Pakenham T The Scramble for Africa (1992), Jonathan Ball, Johannesburg.

Pottinger B The Imperial Presidency (1988) Southern Book Publishers, Johannesburg.

Race Relations Survey 1985 (1986), South African Institute of Race Relations, Johannesburg..

Sachs A Justice in South Africa (1973), University of California Press, Berkeley.

Sampson A The Anatomist (2008), Jonathan Ball, Johannesburg.

"State of Palestine", Wikipedia Encyclopedia, available at: http://wikipedia.org/wiki/State of Palestine, at 2. (Accessed on 30 July 2013)

Scholtz G D Hertzog en Smuts en die Britse Ryk (1975) Randse Afrikaanse Universiteit, Johannesburg.

Slider Encyclopedia, 'Decolonization' http://enc.slider.com/Enc/Decolonization.

Smuts J C Greater South Africa: Plans for a Better World (1940), Truth Legion, Johannesburg.

Smuts J C Holism and Evolution (1927) MacMillan \& Co, London.

Talton B "The Challenge of Decolonization in Africa", available at: http://exhibitions.nypl.org/africanaage/essay-challenge-of-decolonization-africa.html.

Tomlinson R F (Chairman) Report of the Commission for the Socio-Economic Development of the Bantu Areas within the Union of South Africa (full report), chapter 17, (1954) Government Printer, Pretoria.

van der Merwe "Die Totstand-koming van die Republiek van Suid-Afrika 31 Mei 1961" in: Van Jaarsveld F A and

Scholtz G A (eds), Die Republiek van Suid-Afrika (1966) Voortrekker Pers (Johnnesburg).

Venter F Die Suid-Afrikaanse Bantoe Staatsreg, Doctoral Thesis, Potchefstroom University, (PUCHO)) (1978).

Wasserman G Politics of Decolonization (1976), Cambridge University Press, 1976.

Welsh D “Chieftainship under Shepstone” in: The Roots of Segregation (1971) Oxford University Press, Cape Town.

Wheare KC The Constitutional Structure of the Commonwealth (1961) Clarendon Press, Oxford.

Wiechers M Staatsreg (1981), Butterworths, Durban.

Wilson M and Thompson L (eds) The Oxford History of South Africa (1978), Oxford University Press, Oxford.

World Book Encyclopedia (1992), Vol. 1, World Book, Inc, London.

World Book Encyclopedia (1992), Vol. 2, World Book, Inc, London.

W orld Book Encyclopedia (1992), Vol. 3, World Book Inc, London.

World Book Encyclopedia (1992), Vol. 10, World Book Inc, London.

World Book Encyclopedia (1992), Vol. 14, World Book, Inc, London. 
World Book Encyclopedia (1992), Vol. 19, World Book, Inc, London.

"Yugoslavia", available at: http://en.wikipedia.org/wiki/Yugoslavia, at 1 (Accessed 30 July 2013). 